\title{
sciendo
}

Current Issues in Pharmacy and Medical Sciences

Formerly ANNALES UNIVERSITATIS MARIAE CURIE-SKLODOWSKA, SECTIO DDD, PHARMACIA

journal homepage: http://www.curipms.umlub.pl/

\section{An overview of techniques for multifold enhancement in solubility of poorly soluble drugs}

\author{
Mohammad Javed Ansari* ${ }^{*}$
}

Department of Pharmaceutics, College of Pharmacy, Prince Sattam Bin Abdul Aziz University, Al-Kharj, Saudi Arabia

\begin{tabular}{l}
\hline ARTICLE INFO \\
\hline Received 05 February 2019 \\
Accepted 24 April 2019
\end{tabular}

Keywords:

poorly soluble drugs,

solubility, dissolution,

bioavailability,

salt formation,

solid dispersion,

complexation,

co-crystallization.

\begin{abstract}
Poor water solubility of newly discovered compounds has become the most common challenge in the drug development process. Indeed, poor solubility is considered as the root cause of failure of drug during drug development phases. Moreover, it has also been reported to be the main reason for bioavailability issues such as poor, inconsistent, incomplete and highly variable bioavailability of the marketed products. As per an estimate, approximately $90 \%$ of drug molecules suffer with poor water solubility at early stage and approximately $40 \%$ of the marketed drugs have bioavailability problems mainly due to poor water solubility. Solubility enhancement of the newly discovered compounds is primary research area for the pharmaceutical industries and research institutions. The conventional techniques to improve aqueous solubility of drugs employ salt formation, prodrug formation, co-crystallization, complexation, amorphous solid dispersion and use of co-solvent, surfactants or hydrotropic agents. Current advancement in the science and technology has enabled the use of relatively new techniques under the umbrella of nanotechnology. These include the development of nanocrystals, nanosuspensions, nanoemulsions, microemulsions, liposomes and nanoparticles to enhance the solubility. This review focuses on the conventional and current approaches of multifold enhancement in the solubility of poorly soluble marketed drugs, including newly discovered compounds.
\end{abstract}

\section{INTRODUCTION}

Combinatorial chemistry and high throughput screening techniques have been employed by pharmaceutical industries to hasten their drug discovery and development processes $[1,2]$. These techniques have enabled to synthesize and test a very huge number of compounds per day. As a result, a large number of new chemical entities or potential drug candidates are introduced or discovered for a particular diseased condition. However, that is not the end of the process, as further drug development encounters several challenges. Among these are solubility, permeability, stability, safety and efficacy etc. The aforementioned deaccelerate drug development and delay the drug approval process [3-5]. Among these challenges, poor water solubility of the newly discovered compounds has appeared as the most common challenge in the early drug development, while inefficacy was found as main reason of drug failure in later drug development phases such as phase II. It has been reported that high throughput screening (HTS)-based

\footnotetext{
* Corresponding author

e-mail:mj.ansari@psau.edu.sa
}

approaches are linked with lipophilicity, molecular weight and $\mathrm{H}$-bonding properties leading to poor aqueous solubility of the newly discovered compounds [6]. As per an estimate, approximately $90 \%$ of drug molecules suffer with poor water solubility at early stage, while approximately $40 \%$ of the marketed drugs have bioavailability problems mainly due to poor water solubility [7].

The poor solubility challenge can be overcome by using various conventional and advanced techniques. For instance, conventional methods such as salt formation [8], prodrug [9], co-solvent [10], micellar solublization [11], hydrotrophy [12], complexation [13], co-crystallization [14] and amorphous solid dispersion [15] have been employed to enhance solubility of several poorly soluble drugs. Advanced methods for solubility enhancement are generally based on nanotechnology that include either nanonization or nanoencapsulation of poorly soluble drugs. In this regard, nanocrystal [16], nanosuspension [17], nanoemulsion [18], microemulsion [19] and nanoparticles [20] have been investigated for the improvement of solubility or bioavailability of challenging drug candidates. 
CONVENTIONAL TECHNIQUES TO IMPROVE SOLUBILITY OF DRUGS

There are several conventional techniques to improve solubility of the drugs as shown in Figure 1.

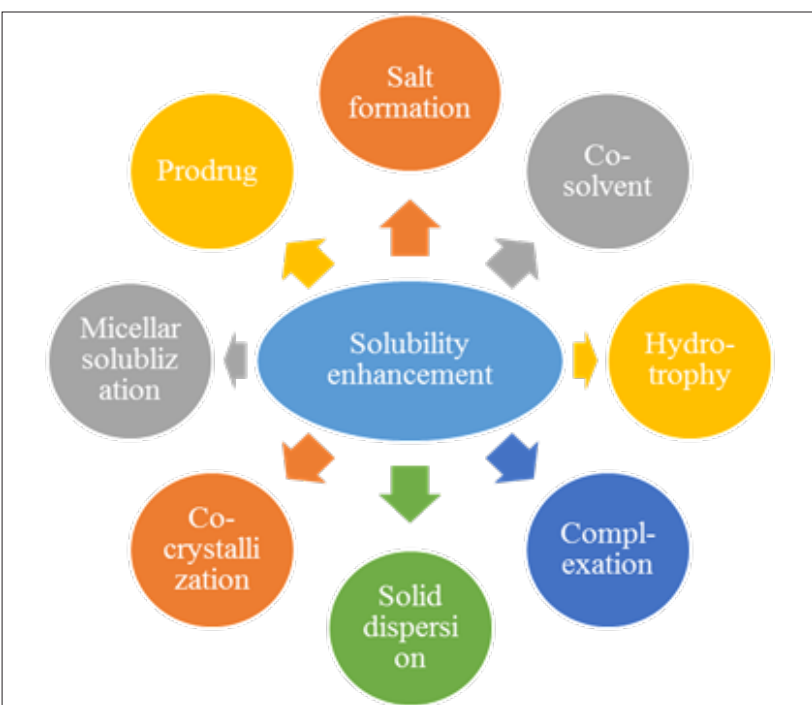

Figure 1. Conventional techniques of solubility enhancement

\section{Enhancement in solubility of drugs through salt formation}

Improvement of solubility of drug by preparing its salt is a classical technique and can be traced back to the 1970s $[21,22]$. As most of the newly discovered drugs are either acidic or basic in nature, these can be converted to their soluble salt forms to enhance water solubility (Table 1).

Table 1. List of some poorly soluble drugs, their salt forms and degree of solubility enhancement

\begin{tabular}{|l|l|c|c|}
\hline \multicolumn{1}{|c|}{ Drug } & \multicolumn{1}{c|}{ Salt form } & $\begin{array}{c}\text { Solubility } \\
\text { enhancement }\end{array}$ & Reference \\
\hline Pyridoclax & Dihydrochloride & 4 fold & {$[23]$} \\
\hline Sildenafil & Glutarate salt & 3.2 fold & {$[24]$} \\
\hline Furosemide & Sodium salt & 20 fold & {$[25]$} \\
\hline Phenytoin & Sodium salt & 60 fold & {$[26]$} \\
\hline Bupivacaine & Chloride salt & 200 fold & {$[27]$} \\
\hline Indomethacin & Arginine \& lysine & $\begin{array}{c}10000 \& \\
2296 \text { fold }\end{array}$ & {$[28]$} \\
\hline
\end{tabular}

\section{Enhancement in solubility through prodrug approach}

The prodrug approach is also one of the classical techniques for solubility enhancement. Prodrugs are inactive compounds consisting of parent drug with or without carrier that are potentiated due to release of active drug in the body through some chemical or enzymatic cleavage. Prodrugs can either be bipartite wherein the drug is directly attached with the carrier or tripartite - containing a spacer between drug and carrier. The inert carriers are commonly attached with the drug by functional groups - amides, carbamates, carbonates, esters, ethers, imines and phosphates, etc. [29] (Table 2).
Table 2. Poorly soluble drugs, prodrug derivatives and degree of solubility enhancement

\begin{tabular}{|c|c|c|c|}
\hline Drug & Prodrug derivative & $\begin{array}{c}\text { Solubility } \\
\text { enhancement }\end{array}$ & Reference \\
\hline Bupivacaine base & $\begin{array}{l}\text { N-butanoyloxymethyl } \\
\text { derivative }\end{array}$ & 10,000 fold & [30] \\
\hline $\begin{array}{l}\text { Trifluoromethyl } \\
\text { ketone }\end{array}$ & $\begin{array}{l}\text { 1,1,1-trifluoro-3-(octane- } \\
1 \text {-sulfonyl)-propan-2,2- } \\
\text { diol \& } \\
\text { 1,1,1-trifluoro-3- } \\
\text { octylsulfanyl-propan-2- } \\
\text { one derivative }\end{array}$ & 10 fold & [31] \\
\hline Paclitaxel & Dihydroxyl derivative & 50 fold & [32] \\
\hline Phosphoramidates & Tyrosine derivative & 30 fold & [33] \\
\hline Thiabendazole & $\begin{array}{l}\mathrm{N} \text {-alkoxycarbonyl \& } \\
\mathrm{N} \text {-(4-amino- } \\
\text { methylbenzoyl)oxymethyl } \\
\text { derivative }\end{array}$ & $12 \& 300$ fold & [34] \\
\hline Lamivudine & 5'-O-carbonates & 70 fold & [35] \\
\hline $\begin{array}{l}\text { 3-Carboranyl } \\
\text { Thymidine Analogs }\end{array}$ & $\begin{array}{l}\text { L-valine-, L-glutamate-, } \\
\text { and glycine ester } \\
\text { derivatives }\end{array}$ & $48-6600$ fold & [36] \\
\hline Metronidazole & $\begin{array}{l}\mathrm{N}, \mathrm{N} \text {-diethylglycinate } \\
\text { hydrochloride }(3 \mathrm{a}) \& \\
\text { 4-ethylpiperazinoacetate } \\
\text { (3e) derivatives }\end{array}$ & $140 \& 100$ fold & [37] \\
\hline
\end{tabular}

\section{Enhancement in solubility through co-solvent approach}

The co-solvent approach of enhancing water solubility of poorly soluble drugs involves mixing water-miscible nontoxic organic solvent with water. This improves the solvent action of water, leading to the solublization of poorly soluble drugs. The commonly used co-solvents include ethanol, glycerol, propylene glycol and polyethylene glycols [38] (Table 3).

Table 3. Poorly soluble drugs, co-solvent derivatives and degree of solubility enhancement

\begin{tabular}{|l|l|c|c|}
\hline \multicolumn{1}{|c|}{ Drug } & \multicolumn{1}{|c|}{ Co-solvents } & $\begin{array}{c}\text { Solubility } \\
\text { enhancement }\end{array}$ & Reference \\
\hline $\begin{array}{l}\text { Methyl propyl } \\
\text { trisulfide }\end{array}$ & Ethanol and cremophur & 2900 fold & {$[39]$} \\
\hline Ethyl-paraben & Nicotinamide & 2 fold & {$[40]$} \\
\hline 6-mercaptopurine & $\begin{array}{l}\text { Sodium benzoate \& sodium } \\
\text { hippurate }\end{array}$ & 6 fold & {$[41]$} \\
\hline Phosphoramidates & Tyrosine derivative & 30 fold & {$[42]$} \\
\hline Enrofloxacin & $\begin{array}{l}\text { Ethanol, glycerol, PEG 400, } \\
\text { propylene glycol }\end{array}$ & 1.1 -3.3 fold & {$[43]$} \\
\hline Ferulic acid & Isopropanol & $\begin{array}{c}\text { Approx. 53 } \\
\text { fold }\end{array}$ & {$[44]$} \\
\hline
\end{tabular}

\section{Enhancement in solubility through micellar solublization}

The micellar solublization approach is based on the fact that surfactants, owing to their amphiphilic nature, associate spontaneously in anisotropic clusters known as 'micelles'. These contain a hydrophobic center and hydrophilic surfaces. Poorly soluble or water insoluble drugs are enclosed in the hydrophobic centers of micelles, thus become solubilized. It is noteworthy that association or aggregation of surfactant molecules occur at a particular concentration called the 'critical micelle concentration' (CMC). The lower the CMC value of a particular surfactant, the more stable a micelle is formed [45] (Table 4). 
Table 4. Poorly soluble drugs, surfactants and degree of solubility enhancement

\begin{tabular}{|c|c|c|c|}
\hline Drug & Surfactants & \begin{tabular}{|c|} 
Solubility \\
Enhancement
\end{tabular} & References \\
\hline Apigenin & $\begin{array}{l}\text { Soluplus } \AA \text { and Pluronic } \\
\text { F127 }\end{array}$ & 3442 fold & [46] \\
\hline Ibuprofen & Poloxamer 407 & 18 fold & [47] \\
\hline Fenofibrate & Sodium lauryl sulfate & 2000 fold & [48] \\
\hline Raloxifene & Igepal CO-890 & 2 fold & [49] \\
\hline Celecoxib & $\begin{array}{l}\text { Quaternary-ammonium- } \\
\text { palmitoyl-glycol-chitosan }\end{array}$ & 60 fold & {$[50]$} \\
\hline Sirolimus & $\begin{array}{l}\text { Tocopheryl polyethylene } \\
\text { glycol succinate }\end{array}$ & 400 fold & [51] \\
\hline Artemisinin & Sodium dodecyl sulphate & 50 fold & {$[52]$} \\
\hline Griseofulvin & $\begin{array}{l}\text { SDS, CTAB, Tween 80, and } \\
\text { Cremophor EL. }\end{array}$ & $\begin{array}{c}104,31,4 \& \\
3 \text { fold }\end{array}$ & [53] \\
\hline Penicillin V & $\begin{array}{l}\text { Polyoxyethylene-23-lauryl } \\
\text { ether }\end{array}$ & 3 fold & [54] \\
\hline
\end{tabular}

\section{Enhancment in solubility through hydrotropic agents}

The hydrotropic solublization approach involves the addition of excess hydrotropic agents (hydrophilic inert solutes or polymers) to improve the solubility. Hydrotropic agents are amphiphilic and contain both a hydrophilic head group and a hydrophobic tail group. This is similar to the surfactants, however, herein, the hydrophobic tail is too small to cause spontaneous self-aggregation as observed in micellar solublization. Nevertheless, a unique association (stack-type aggregation) does occur at substantially higher concentrations of hydrotropic agents [55] (Table 5).

Table 5. Poorly soluble drugs, hydrotropic agents and degree of solubility enhancement

\begin{tabular}{|c|c|c|c|}
\hline Drugs & Hydrotropic agents & $\begin{array}{c}\text { Solubility } \\
\text { Enhancement }\end{array}$ & References \\
\hline Nevirapine & $\begin{array}{l}\text { Urea, lactose, citric acid and } \\
\text { mannitol }\end{array}$ & $\begin{array}{c}27,11,42 \& \\
10 \text { fold } \\
\end{array}$ & {$[56]$} \\
\hline Carbamazepine & Nicotinamide and urea & 30 fold & [57] \\
\hline Lurasidone & $\begin{array}{l}\text { Nicotinamide, sodium } \\
\text { citrate, urea and sodium } \\
\text { benzoate }\end{array}$ & $12-61$ fold & {$[58]$} \\
\hline Furosemide & $\begin{array}{l}\text { Urea, sodium acetate, } \\
\text { sodium benzoate, sodium } \\
\text { citrate }\end{array}$ & $16-296$ fold & [59] \\
\hline Riboflavin & Nicotinamide and urea & 20 fold & {$[60]$} \\
\hline
\end{tabular}

\section{Enhancement in solubility through complexation approach}

The complexation approach of enhancing drug solubility is a classical and commonly used method. Moreover, this approach is one of the most successful - as evident by several challenging drug products on the market, the solubility of which was improved by complexation. Examples include Prostarmon-E ${ }^{\mathrm{TM}}$ sublingual tablets (prostaglandin complexed with cyclodextrin, 1976), Brexin $\AA$ tablets (Piroxicam complexed with $\beta-C D, 1977$ ) and Sporanox ${ }^{\circledR}$ (itraconazole/2-hydroxypropyl- $\beta C D$ oral solution) $[61,62]$. Inclusion complexes are special kinds of complexes wherein the guest molecule (the hydrophobic drug to be included) fits non-covalently in the inner hydrophobic cavity of the host molecule (the complexing agent). Thus, the poorly soluble hydrophobic drug substance becomes more soluble as it is in a water that contains complexing agents. Complexation of drugs with complexing agents depends on the polarity and size of the host and guest molecule. Cyclodextrins, the cyclic sugars, are the most commonly used complexing agent for the improvement of solubility, owing to the availability of different host molecule cavity sizes [63] (Table 6).

Table 6. Poorly soluble drugs, their complexing agents and degree of solubility enhancement

\begin{tabular}{|l|l|c|c|}
\hline \multicolumn{1}{|c|}{ Drugs } & \multicolumn{1}{|c|}{ Complexing agents } & $\begin{array}{c}\text { Solubility } \\
\text { Enhancement }\end{array}$ & References \\
\hline Nerolidol & $\begin{array}{l}\text { Hydroxypropyl-beta- } \\
\text { cyclodextrin }\end{array}$ & 70 fold & {$[64]$} \\
\hline Pseudolaric acid & $\begin{array}{l}\text { Hydroxypropyl-beta- } \\
\text { cyclodextrin }\end{array}$ & 600 fold & {$[65]$} \\
\hline $\begin{array}{l}\text { SN-38 (irinotecan } \\
\text { metabolite) }\end{array}$ & Cyclodextrin derivatives & $30-1,400$ fold & {$[66]$} \\
\hline Astilbin & $\beta$-cyclodextrin & 122 fold & {$[67]$} \\
\hline Dihydroartemisinin & $\begin{array}{l}\text { Hydroxypropyl-beta- } \\
\text { cyclodextrin }\end{array}$ & 89 fold & {$[68]$} \\
\hline Glyburide & $\begin{array}{l}\text { Hydroxybutenyl-beta- } \\
\text { cyclodextrin }\end{array}$ & 400 fold & {$[69]$} \\
\hline Phenytoin & $\begin{array}{l}\text { Hydroxypropyl } \\
\text { betacyclodextrin and Methyl } \\
\text { beta-cyclodextrin }\end{array}$ & $\begin{array}{c}420 \& 578- \\
\text { fold }\end{array}$ & {$[70]$} \\
\hline Icariin & $\beta$-cyclodextrin & 36 fold & {$[71]$} \\
\hline Naringin & $\beta$-cyclodextrin & 15 fold & {$[72]$} \\
\hline Silymarin & $\beta$-cyclodextrin & 6.7 fold & {$[73]$} \\
\hline
\end{tabular}

\section{Enhancment in solubility through co-crystal approach}

Cocrystals are a crystalline mixture consisting of an active pharmaceutical agent bonded non-covalently with an inactive pharmaceutical agent called a 'conformer' [74]. The advantage of co-crystal enhancement is that any kind of drug, whether acid, base or neutral, can be co-crystallized, unlike salt formations which require that the drug must possess certain characteristics. Cocrystals are high energy forms and are known to increase solubility of the included drugs due to rapid dissociation in the medium, thus creating a supersaturated drug [75] (Table 7).

Table 7. Poorly soluble drugs, their coformers and the degree of solubility enhancement

\begin{tabular}{|l|l|c|c|}
\hline \multicolumn{1}{|c|}{ Drug } & \multicolumn{1}{|c|}{ Coformers } & $\begin{array}{c}\text { Solubility } \\
\text { Enhancement }\end{array}$ & References \\
\hline Hydrochlorothiazide & $\begin{array}{l}\text { Nicotinic acid, } \\
\text { nicotinamide, succinamide, } \\
\text { p-aminobenzoic acid, } \\
\text { resorcinol and pyrogallol }\end{array}$ & $1.5-6$ fold & {$[76]$} \\
\hline Carbamazepine & Cinnamic acid & 152 fold & {$[77]$} \\
\hline Indomethacin & Saccharin & $13-65$ fold & {$[78]$} \\
\hline Furosemide & $\begin{array}{l}\text { Caffeine, Adenine \& } \\
\text { Cytosine }\end{array}$ & $6,7 \& 11$ fold & {$[79]$} \\
\hline Andrographolide & Salicylic acid & 12 fold & {$[80]$} \\
\hline
\end{tabular}

\section{Enhancment in solubility through solid dispersions}

Solid dispersions are amorphous mixtures of solid drug in solid matrix (inactive small molecule or polymer) at molecular levels. Solid dispersions result in supersaturated drug solutions which may precipitate before being absorbed, therefore, components to inhibit drug precipitation should be added into solid dispersions [81]. Fortunately, the most commonly used polymer matrix for solid dispersions, polyvinylpyrrolidone and hydroxypropyl methylcellulose, are known to prevent drug precipitation [81]. The solid dispersion approach is considered a successful and commercially viable method as evidenced by various marketed solid dispersion formulations (Table 8). 
Table 8. Poorly soluble drugs, their dispersants and degree of solubility enhancement

\begin{tabular}{|l|l|c|c|}
\hline \multicolumn{1}{|c|}{ Drug } & \multicolumn{1}{|c|}{ Dispersants } & $\begin{array}{c}\text { Solubility } \\
\text { Enhancement }\end{array}$ & References \\
\hline Cefdinir & $\begin{array}{l}\text { Hydroxypropyl- } \\
\text { methylcellulose, } \\
\text { carboxymethylcellulose-Na, } \\
\text { polyvinyl pyrrolidone K30 }\end{array}$ & 9 fold & {$[82]$} \\
\hline Clotrimazole & $\begin{array}{l}\text { D-mannitol, d-fructose, } \\
\text { d-dextrose and d-maltose }\end{array}$ & $43-806$ fold & {$[83]$} \\
\hline Docetaxel & Soluplus & 93 fold & {$[84]$} \\
\hline Carvedilol & Tween 80/PVP K30 & 11,500 & {$[85]$} \\
\hline Tranilast & Eudragit EPO & 3000 fold & {$[86]$} \\
\hline Tacrolimus & $\begin{array}{l}\text { Hydroxypropyl-beta- } \\
\text { cyclodextrin }\end{array}$ & 900 fold & {$[87]$} \\
\hline Itraconazole & Eudragit E 100 & $141.4-146.9-$ & {$[88]$} \\
\hline Carvedilol & $\begin{array}{l}\text { Hydroxypropyl- } \beta- \\
\text { cyclodextrin }+ \text { tartric acid }\end{array}$ & 340 fold & {$[89]$} \\
\hline Carvedilol & $\begin{array}{l}\text { Hydroxypropyl- } \\
\beta \text {-cyclodextrin }+ \\
\text { Polyvinylpyrrolidone K-30 }\end{array}$ & 70 fold & {$[90]$} \\
\hline Repaglinide & Eudragit E100 & 100 fold & {$[91]$} \\
\hline Nilotinib & Soluplus & 630 fold & {$[92]$} \\
\hline Ritonavir & Lyophilized milk & 30 fold & {$[93]$} \\
\hline Miconazole Nitrate & $\begin{array}{l}\text { Beta-cyclodextrin }(\beta-C D) \\
+ \text { PVP }\end{array}$ & $\begin{array}{c}72 \text { folds and } \\
316 \text { folds }\end{array}$ & {$[94]$} \\
\hline $\begin{array}{l}\text { Candesartan } \\
\text { cilexetil }\end{array}$ & $\begin{array}{l}\text { Hydroxypropyl- } \beta- \\
\text { cyclodextrin }=\text { PEG } 6000\end{array}$ & 22 fold & {$[95]$} \\
\hline Curcumin & $\begin{array}{l}\text { PVP K30 } \\
880 \text { fold }\end{array}$ & {$[96]$} \\
\hline
\end{tabular}

\section{NANOTECHNOLOGY APPROACH TO IMPROVE SOLUBILITY OF DRUGS}

Nanotechnology is a recently emerged multidisciplinary scientific technology dealing with objects or materials at nanoscale. It is not a new discipline of science such as physics or chemistry, rather it is a new technology expanding into almost every domain of science, including material sciences, chemical sciences, electronic and health sciences. Nano-medicine and nanotechnology in drug delivery has witnessed a substantial growth in health-care researches owing to its huge potential. In 2014, the global market share was $\sim 41$ bn USD and this is expected to reach $\sim 120$ bn USD by 2023 [97]. Nano carriers - liposomes, microemulsions, nano-emulsions, nanoparticles, nano-suspensions and nano-crystals - have been investigated to address issues such as poor solubility, poor permeability, instability, and the unsuitable pharmacokinetic profiles of certain existing drugs. The investigation of nano formulations to address specific disease or drug related issues could be traced back to 1970 s, however, their application to improve drug solubility has only bee recently approved $[98,99]$. The nanofabrication techniques of solubility enhancement (Figure 2), whether based on lipoid carriers such as fabrication of liposomes, microemulsions, nano-emulsions, or based on polymeric carriers such as fabrication of nanoparticles, nanosuspensions and nano-crystals, generally result in enormous increase in surface area of the fabricated nano-medicines, thereby improving saturated solubility and rate of dissolution [100].

Liposomes are nano-sized bilayer vesicles of phospholipids that contain hydrophobic bilayer periphery and an aqueous hydrophilic cavity [101]. These are capable of enclosing both hydrophilic, as well as hydrophobic drugs. Microemulsions and nanoemulsions are colloidal emulsions

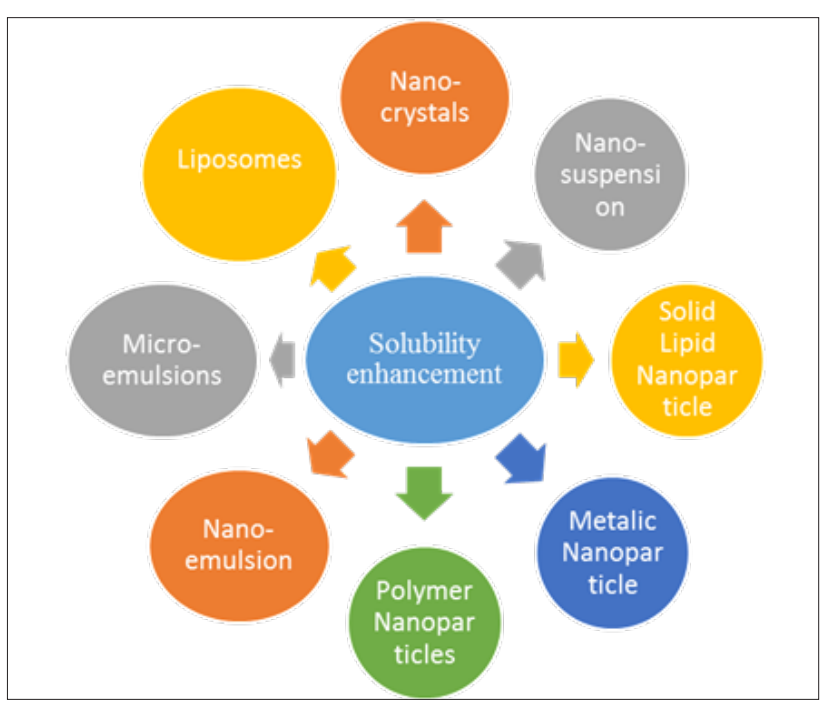

Figure 2. Nanofabrication techniques of solubility enhancement

containing a dispersed phase at nano-sized scale. Microemulsions are produced spontaneously by gentle mixing of oil, water and appropriate amounts of emulsifier and coemulsifier [102]. Nanoemulsions, in contrast, are produced with the help of high-energy mixers or homogenizers. Polymeric nanoparticles or nanosuspensions are nanosized drug materials enclosed within a polymeric matrix or shell generally produced by way of utilizing the nanoprecipitation technique. Herein, slow addition of the organic solution of drug and polymer in an antisolvent induces nanoprecipitation and stabilization of the drug after encapsulation within polymeric nanoparticles [103] (Table 9).

Table 9. Poorly soluble drugs, the nanotechnology employed and the degree of solubility enhancement

\begin{tabular}{|c|c|c|c|}
\hline Drug & Dispersants & $\begin{array}{c}\text { Solubility } \\
\text { Enhancement }\end{array}$ & References \\
\hline Fusidic acid & Poloxamer-188 & 8 fold & [104] \\
\hline Curcumin & $\beta$-lactoglobulin & $\sim 35$-fold & [105] \\
\hline Lacidipine & Sodium deoxycholate & 70 fold & [106] \\
\hline Apigenin & Phospholipid phytosome & 36 fold & [107] \\
\hline Silymarin & Water-soluble chitosan & 7.7 fold & [108] \\
\hline Lutein & $\begin{array}{l}\text { Poly (lactic-co-glycolic } \\
\text { acid) (PLGA)-polyethylene } \\
\text { glycol (PEG) }\end{array}$ & 735 fold & [109] \\
\hline Pyridoclax & Tween 80 & 1000 fold & {$[110]$} \\
\hline $\begin{array}{l}\text { 10-methoxy-9- } \\
\text { nitrocamptothecin }\end{array}$ & $\begin{array}{l}\text { Lipoid E80 and cremophor } \\
\text { EL }\end{array}$ & 200 fold & [111] \\
\hline Resveratrol & $\begin{array}{l}\text { Castor oil, Capmul, } \\
\text { Cremophor EL/RH 40/ } \\
\text { RH60) }\end{array}$ & 23 fold & [112] \\
\hline $\begin{array}{l}\text { Progesterone } \\
\text { and indomethacin }\end{array}$ & $\begin{array}{l}\text { Isopropyl myristate-based } \\
\text { microemulsion }\end{array}$ & $500-3300$ & [113] \\
\hline
\end{tabular}

\section{CONCLUSIONS}

There are several conventional and advanced methods of solubility enhancement. Each method has its own merits and demerits, which need to be considered at the time of selection of the method. Moreover, permeability and stability inside the body are also needed to be considered, as mere solubility enhancement in the laboratory would not be beneficial in real application of improvement of performance of the drug. 


\section{CONFLICT OF INTEREST}

We declare that there is conflict of interest.

\section{AUTHOR CONTRIBUTIONS}

Mohammad Javed Ansari: Conceptualization, Literature search and Manuscript writing.

Saad M Al-Shahrani: Draft Editing and final reviewing.

\section{ORCID iDs}

Mohammad Javed Ansari

(D)https://orcid.org/0000-0001-9266-7133

\section{REFERENCES}

1. Liu R, Li X, Lam KS. Combinatorial chemistry in drug discovery. Curr Opin Chem Biol. 2017;38:117-26.

2. Macarron R, Banks MN, Bojanic D, Burns DJ, Cirovic DA, Garyantes T, et al. Impact of high-throughput screening in biomedical research. Nat Rev Drug Discov. 2011;10(3):188-95.

3. Khanna I. Drug discovery in pharmaceutical industry: productivity challenges and trends. Drug Discov Today. 2012;17(19-20):1088-102.

4. Gardner CR, Walsh CT, Almarsson Ö. Drugs as materials: valuing physical form in drug discovery. Nat. Rev. Drug Discov. 2004;3(11): 926-34.

5. Huang LF, Tong WQ. Impact of solid state properties on developability assessment of drug candidates. Adv Drug Deliv Rev. 2004;56(3): 321-34.

6. Lipinski CA. Drug-like properties and the causes of poor solubility and poor permeability. J Pharmacol Toxicol Methods. 2000;44(1): 235-49.

7. Kalepu S, Nekkanti V. Insoluble drug delivery strategies: review of recent advances and business prospects. Acta Pharm Sinica B. 2015; 5(5):442-53.

8. Serajuddin AT. Salt formation to improve drug solubility. Adv Drug Del Rev. 2007;59(7):603-16.

9. Stella VJ, Nti-Addae KW. Prodrug strategies to overcome poor water solubility. Adv Drug Del Rev. 2007;59(7):677-94.

10. Seedher N, Kanojia M. Co-solvent solubilization of some poorlysoluble antidiabetic drugs. Pharm Dev Tech. 2009;14(2):185-92.

11. Rangel-Yagui CO, Pessoa Jr A, Tavares LC. Micellar solubilization of drugs. J Pharm Pharm Sci. 2005;8(2):147-63.

12. Sintra TE, Shimizu K, Ventura SP, Shimizu S, Lopes JC, Coutinho JA. Enhanced dissolution of ibuprofen using ionic liquids as catanionic hydrotropes. Phy Chem Chem Phy. 2018;20(3):2094-103.

13. Loftsson T, Brewster ME. Pharmaceutical applications of cyclodextrins. 1. Drug solubilization and stabilization. J Pharm Sci. 1996;85(10):1017-25.

14. Thakuria R, Delori A, Jones W, Lipert MP, Roy L, RodríguezHornedo N. Pharmaceutical cocrystals and poorly soluble drugs. Int J Pharm. 2013;453(1):101-25.

15. Leuner C, Dressman J. Improving drug solubility for oral delivery using solid dispersions. Eur J Pharm Biopharm. 2000;50(1):47-60.

16. Shegokar R, Müller RH. Nanocrystals: industrially feasible multifunctional formulation technology for poorly soluble actives. Int J Pharm. 2010;399(1-2):129-39.

17. Müller RH, Peters K. Nanosuspensions for the formulation of poorly soluble drugs: I. Preparation by a size-reduction technique. Int $J$ Pharm. 1998;160(2):229-37.

18. Kotta S, Khan AW, Pramod K, Ansari SH, Sharma RK, Ali J. Exploring oral nanoemulsions for bioavailability enhancement of poorly water-soluble drugs. Expert Opin Drug Del. 2012;9(5):585-98.

19. $\mathrm{He} \mathrm{CX,} \mathrm{He} \mathrm{ZG,} \mathrm{Gao} \mathrm{JQ.} \mathrm{Microemulsions} \mathrm{as} \mathrm{drug} \mathrm{delivery} \mathrm{systems} \mathrm{to}$ improve the solubility and the bioavailability of poorly water-soluble drugs. Expert Opin Drug Del. 2010;7(4):445-60.

20. Hu J, Johnston KP, Williams III RO. Nanoparticle engineering processes for enhancing the dissolution rates of poorly water soluble drugs. Drug Dev Ind Pharm. 2004;30(3):233-45.
21. Miyazaki S, Nakano M, Arita T. A comparison of solubility characteristics of free bases and hydrochloride salts of tetracycline antibiotics in hydrochloric acid solutions. Chem Pharm Bull (Tokyo). 1975;23(6):1197-204.

22. Agharkar S, Lindenbaum S, Higuchi T. Enhancement of solubility of drug salts by hydrophilic counterions: properties of organic salts of an antimalarial drug. J Pharm Sci. 1976;65(5):747-9.

23. Groo AC, De Pascale M, Voisin-Chiret AS, Corvaisier S, Since M, Malzert-Fréon A. Comparison of 2 strategies to enhance pyridoclax solubility: Nanoemulsion delivery system versus salt synthesis. Eur J Pharm Sci. 2016;97:218-226.

24. Sanphui P, Tothadi S, Ganguly S, Desiraju GR. Salt and cocrystals of sildenafil with dicarboxylic acids: solubility and pharmacokinetic advantage of the glutarate salt. Mol Pharm. 2013;10(12):4687-97.

25. Nielsen LH, Gordon S, Holm R, Selen A, Rades T, Müllertz A. Preparation of an amorphous sodium furosemide salt improves solubility and dissolution rate and leads to a faster Tmax after oral dosing to rats. Eur J Pharm Biopharm. 2013;85(3 Pt B):942-51.

26. Chiang PC, Wong H. Incorporation of physiologically based pharmacokinetic modeling in the evaluation of solubility requirements for the salt selection process: a case study using phenytoin. AAPS J. 2013;15(4):1109-18.

27. Nielsen AB, Frydenvang K, Liljefors T, Buur A, Larsen C. Assessment of the combined approach of $\mathrm{N}$-alkylation and salt formation to enhance aqueous solubility of tertiary amines using bupivacaine as a model drug. Eur J Pharm Sci. 2005;24(1):85-93.

28. ElShaer A, Khan S, Perumal D, Hanson P, Mohammed AR. Use of amino acids as counterions improves the solubility of the BCS II model drug, indomethacin. Curr Drug Deliv. 2011;8(4):363-72.

29. Jornada DH, dos Santos Fernandes GF, Chiba DE, De Melo TR, Dos Santos JL, Chung MC. The prodrug approach: a successful tool for improving drug solubility. Molecules. 2015;21(1):42.

30. Nielsen AB, Buur A, Larsen C. Bioreversible quaternary $\mathrm{N}$-acyloxymethyl derivatives of the tertiary amines bupivacaine and lidocaine--synthesis, aqueous solubility and stability in buffer, human plasma and simulated intestinal fluid. Eur J Pharm Sci. 2005;24(5):433-40.

31. Sanphui P, Tothadi S, Ganguly S, Desiraju GR. Salt and cocrystals of sildenafil with dicarboxylic acids: solubility and pharmacokinetic advantage of the glutarate salt. Mol Pharm. 2013;10(12):4687-97.

32. Niethammer A, Gaedicke G, Lode HN, Wrasidlo W. Synthesis and preclinical characterization of a paclitaxel prodrug with improved antitumor activity and water solubility. Bioconjug Chem. 2001;12(3):414-20.

33. Siddiqui A, McGuigan C, Ballatore C, Srinivasan S, De Clercq E, Balzarini J. Enhancing the aqueous solubility of d4T-based phosphoramidate prodrugs. Bioorg Med Chem Lett. 2000;10(4): 381-4.

34. Nielsen LS, Bundgaard H, Falch E. Prodrugs of thiabendazole with increased water-solubility. Acta Pharm Nord. 1992;4(1):43-9.

35. Gualdesi MS, Ravetti S, Raviolo MA, Briñón MC. Preformulation studies of novel 5'-O-carbonates of lamivudine with biological activity: solubility and stability assays. Drug Dev Ind Pharm. 2014; 40(9):1246-52.

36. Hasabelnaby S, Goudah A, Agarwal HK, abd Alla MS, Tjarks W. Synthesis,chemical and enzymatic hydrolysis, and aqueous solubility of amino acid ester prodrugs of 3-carboranyl thymidine analogs for boron neutron capture therapy of brain tumors. Eur J Med Chem. 2012;55:325-34.

37. Mahfouz NM, Hassan MA. Synthesis, chemical and enzymatic hydrolysis, and bioavailability evaluation in rabbits of metronidazole amino acid ester prodrugs with enhanced water solubility. J Pharm Pharmacol. 2001;53(6):841-8.

38. Jouyban, A. Review of the cosolvency models for predicting solubility of drugs in water-cosolvent mixtures. J Pharm Pharm Sci. 2008;11(1):32-58.

39. Kovacs K, Ancha M, Jane M, Lee S, Angalakurthi S, Negrito M, Rasheed S, Nwaneri A, Petrikovics I. Identification, solubility enhancement and in vivo testing of a cyanide antidote candidate. Eur J Pharm Sci. 2013;49(3):352-8. 
40. Nicoli S, Bilzi S, Santi P, Caira MR, Li J, Bettini R. Ethyl-paraben and nicotinamide mixtures: apparent solubility, thermal behavior and X-ray structure of the 1:1 co-crystal. J Pharm Sci. 2008;97(11):4830-9.

41. Takeichi Y, Kimura T. Improvement of aqueous solubility and rectal absorption of 6-mercaptopurine by addition of sodium benzoate. Biol Pharm Bull. 1994;17(10):1391-4.

42. Siddiqui A, McGuigan C, Ballatore C, Srinivasan S, De Clercq E, Balzarini J. Enhancing the aqueous solubility of d4T-based phosphoramidate prodrugs. Bioorg Med Chem Lett. 2000;10(4):381-4.

43. Seedher N, Agarwal P. Various solvent systems for solubility enhancement of enrofloxacin. Indian J Pharm Sci. 2009;71(1):82-7.

44. Haq N, Siddiqui NA, Shakeel F. Solubility and molecular interactions of ferulic acid in various (isopropanol + water) mixtures. J Pharm Pharmacol. 2017;69(11):1485-94.

45. Rangel-Yagui CO, Pessoa Jr A, Tavares LC. Micellar solubilization of drugs. J Pharm Pharm Sci. 2005;8(2):147-63.

46. Zhang Z, Cui C, Wei F, Lv H. Improved solubility and oral bioavailability of apigenin via Soluplus/Pluronic F127 binary mixed micelles system. Drug Dev Ind Pharm. 2017;43(8):1276-82.

47. Dugar RP, Gajera BY, Dave RH. Fusion method for solubility and dissolution rate enhancement of ibuprofen using block copolymer poloxamer 407. AAPS PharmSciTech. 2016;17(6):1428-40.

48. Granero GE, Ramachandran C, Amidon GL. Dissolution and solubility behavior of fenofibrate in sodium lauryl sulfate solutions. Drug Dev Ind Pharm. 2005;31(9):917-22.

49. Varshosaz J, Ziaei V, Minaiyan M, Jahanian-Najafabadi A, SayedTabatabaei L. Enhanced solubility, oral bioavailability and antiosteoporotic effects of raloxifene $\mathrm{HCl}$ in ovariectomized rats by Igepal CO-890 nanomicelles. Pharm Dev Technol. 2018,30:1-12.

50. Mennini N, Furlanetto S, Bragagni M, Ghelardini C, Di Cesare Mannelli L, Mura P. Development of a chitosan-derivative micellar formulation to improve celecoxib solubility and bioavailability. Drug Dev Ind Pharm. 2014;40(11):1494-502.

51. Kim MS, Kim JS, Cho WK, Hwang SJ. Enhanced solubility and oral absorption of sirolimus using D-a-tocopheryl polyethylene glycol succinate micelles. ArtifCells Nanomed Biotechnol. 2013;41(2):85-91.

52. Lapenna S, Bilia AR, Morris GA, Nilsson M. Novel artemisinin and curcumin micellar formulations: drug solubility studies by NMR spectroscopy. J Pharm Sci. 2009;98(10):3666-75.

53. Balakrishnan A, Rege BD, Amidon GL, Polli JE. Surfactant-mediated dissolution: contributions of solubility enhancement and relatively low micelle diffusivity. J Pharm Sci. 2004;93(8):2064-75.

54. Tsuji A, Miyamoto E, Matsuda M, Nishimura K, Yamana T. Effects of surfactants on the aqueous stability and solubility of beta-lactam antibiotics. J Pharm Sci. 1982;71(12):1313-8.

55. Balasubramanian D, Srinivas V, Gaikar VG, Sharma MM. Aggregation behavior of hydrotropic compounds in aqueous solution. J Phy Chem. 1989;93(9):3865-70.

56. Madan JR, Kamate VJ, Dua K, Awasthi R. Improving the solubility of nevirapine using A hydrotropy and mixed hydrotropy based solid dispersion approach. Polim Med. 2017;47(2):83-90.

57. Beig A, Lindley D, Miller JM, Agbaria R, Dahan A. Hydrotropic Solubilization of Lipophilic Drugs for Oral Delivery: The Effects of Urea and Nicotinamide on Carbamazepine Solubility-Permeability Interplay. Front Pharmacol. 2016;7(379):1-8.

58. Madan JR, Pawar KT, Dua K. Solubility enhancement studies on lurasidone hydrochloride using mixed hydrotropy. Int J Pharm Investig. 2015;5(2):114-20.

59. Maheshwari RK, Jagwani Y. Mixed hydrotropy: novel science of solubility enhancement. Indian J Pharm Sci. 2011;73(2):179-83.

60. Coffman RE, Kildsig DO. Effect of nicotinamide and urea on the solubility of riboflavin in various solvents. J Pharm Sci. 1996;85(9):951-4.

61. Frank SG, Cho MJ. Phase solubility analysis and PMR study of complexing behavior of dinoprostone with beta-cyclodextrin in water. J Pharm Sci. 1978;67(12):1665-8.

62. Loftsson T, Duchêne D. Cyclodextrins and their pharmaceutical applications. Int J Pharm. 2007;329:1-11.

63. Budhwar V. Cyclodextrin Complexes: An approach to improve the physicochemical properties of drugs and applications of cyclodextrin complexes. Asian J Pharm. 2018;12(02).
64. Azzi J, Danjou PE, Landy D, Ruellan S, Auezova L, Greige-Gerges $\mathrm{H}$, et al. The effect of cyclodextrin complexation on the solubility and photostability of nerolidol as pure compound and as main constituent of cabreuva essential oil. Beilstein J Org Chem. 2017; 13:835-44.

65. Chi L, Liu R, Guo T, Wang M, Liao Z, Wu L, et al. Dramatic improvement of the solubility of pseudolaric acid B by cyclodextrin complexation: preparation, characterization and validation. Int $J$ Pharm. 2015;479(2):349-56.

66. Vangara KK, Ali HI, Lu D, Liu JL, Kolluru S, Palakurthi S. SN-38cyclodextrin complexation and its influence on the solubility, stability, and in vitro anticancer activity against ovarian cancer. AAPS PharmSciTech. 2014;15(2):472-82.

67. Zhang QF, Nie HC, Shangguang XC, Yin ZP, Zheng GD, Chen JG. Aqueous solubility and stability enhancement of astilbin through complexation with cyclodextrins. J Agric Food Chem. 2013; 61(1):151-6.

68. Ansari MT, Iqbal I, Sunderland VB. Dihydroartemisinincyclodextrin complexation: solubility and stability. Arch Pharm Res. 2009;32(1):155-65.

69. Klein S, Wempe MF, Zoeller T, Buchanan NL, Lambert JL, Ramsey MG, et al. Improving glyburide solubility and dissolution by complexation with hydroxybutenyl-beta-cyclodextrin. J Pharm Pharmacol. 2009;61(1):23-30.

70. Latrofa A, Trapani G, Franco M, Serra M, Muggironi M, Fanizzi FP, et al. Complexation of phenytoin with some hydrophilic cyclodextrins: effect on aqueous solubility, dissolution rate, and anticonvulsant activity in mice. Eur J Pharm Biopharm. 2001; 52(1):65-73.

71. Cui L, Zhang Z, Sun E, Jia X, Qian Q. Effect of $\beta$-cyclodextrin complexation on solubility and enzymatic hydrolysis rate of icariin. J Nat Sci Biol Med. 2013;4(1):201-6.

72. Cui L, Zhang ZH, Sun E, Jia XB. Effect of $\beta$-cyclodextrin complexation on solubility and enzymatic conversion of naringin. Int J Mol Sci. 2012;13(11):14251-61.

73. Ansari MJ. Formulation and physicochemical characterization of sodium carboxy methyl cellulose and [beta] cyclodextrin mediated ternary inclusion complexes of silymarin. Int J Pharm Sci Res. 2016; 7(3):984-90.

74. Schultheiss N, Newman A. Pharmaceutical cocrystals and their physicochemical properties. Cryst Growth Des. 2009;9(6):2950-67.

75. Bavishi DD, Borkhataria CH. Spring and parachute: How cocrystals enhance solubility. Prog Cryst Growth Charact Mater. 2016;62(3):1-8.

76. Sanphui P, Rajput L. Tuning solubility and stability of hydrochlorothiazide co-crystals. Acta Crystallogr B Struct Sci Cryst Eng Mater. 2014;70(Pt1):81-90.

77. Keramatnia F, Shayanfar A, Jouyban A. Thermodynamic Solubility Profile of Carbamazepine-Cinnamic Acid Cocrystal at Different pH. J Pharm Sci. 2015;104(8):2559-65.

78. Alhalaweh A, Roy L, Rodríguez-Hornedo N, Velaga SP. $\mathrm{pH}$-dependent solubility of indomethacin-saccharin and carbamazepine-saccharin cocrystals in aqueous media. Mol Pharm. 2012;9(9):2605-12.

79. Goud NR, Gangavaram S, Suresh K, Pal S, Manjunatha SG, Nambiar $S$, et al. Novel furosemide cocrystals and selection of high solubility drug forms. J Pharm Sci. 2012;101(2):664-80.

80. Suresh K, Goud NR, Nangia A. Andrographolide: solving chemical instability and poor solubility by means of cocrystals. Chem Asian J. 2013;8(12):3032-41.

81. Huang Y and Dai WG. Fundamental aspects of solid dispersion technology for poorly soluble drugs. Acta Pharm Sin B. 2004;4(1):18-25.

82. Cho HJ, Jee JP, Kang JY, Shin DY, Choi HG, Maeng HJ, et al. Cefdinir Solid Dispersion Composed of Hydrophilic Polymers with Enhanced Solubility, Dissolution, and Bioavailability in Rats. Molecules. 2017;22(2). pii:E280.

83. Madgulkar A, Bandivadekar M, Shid T, Rao S. Sugars as solid dispersion carrier to improve solubility and dissolution of the BCS class II drug: clotrimazole. Drug Dev Ind Pharm. 2016;42(1):28-38.

84. Kim SM, Pang ZW, Tan HY, Shaikh M, Adinarayana G, Garg S. Enhancement of docetaxel solubility using binary and ternary solid dispersion systems. Drug Dev Ind Pharm. 2015;41(11):1847-55. 
85. Lee SN, Poudel BK, Tran TH, Marasini N, Pradhan R, Lee YI, et al. A novel surface-attached carvedilol solid dispersion with enhanced solubility and dissolution. Arch Pharm Res. 2013;36(1):79-85.

86. Onoue S, Kojo Y, Aoki Y, Kawabata Y, Yamauchi Y, Yamada S. Physicochemical and pharmacokinetic characterization of amorphous solid dispersion of tranilast with enhanced solubility in gastric fluid and improved oral bioavailability. Drug Metab Pharmacokinet. 2012;27(4):379-87.

87. Joe JH, Lee WM, Park YJ, Joe KH, Oh DH, Seo YG, et al. Effect of the solid-dispersion method on the solubility and crystalline property of tacrolimus. Int J Pharm. 2010;395(1-2):161-6.

88. Jung JY, Yoo SD, Lee SH, Kim KH, Yoon DS, Lee KH. Enhanced solubility and dissolution rate of itraconazole by a solid dispersion technique. Int J Pharm. 1999;187(2):209-18.

89. Yuvaraja K, Khanam J. Enhancement of carvedilol solubility by solid dispersion technique using cyclodextrins, water soluble polymers and hydroxyl acid. J Pharm Biomed Anal. 2014;96:10-20.

90. Zoghbi A, Geng T, Wang B. Dual Activity of Hydroxypropyl$\beta$-Cyclodextrin and Water-Soluble Carriers on the Solubility of Carvedilol. AAPS PharmSciTech. 2017;18(8):2927-35.

91. Varshosaz J, Minayian M, Ahmadi M, Ghassami E. Enhancement of solubility and antidiabetic effects of Repaglinide using spray drying technique in STZ-induced diabetic rats. Pharm Dev Technol. 2017;22(6):754-63

92. Herbrink M, Schellens JHM, Beijnen JH, Nuijen B. Improving the solubility of nilotinib through novel spray-dried solid dispersions. Int J Pharm. 2017;529(1-2):294-302.

93. Dhore PW, Dave VS, Saoji SD, Bobde YS, Mack C, Raut NA. Enhancement of the aqueous solubility and permeability of a poorly water soluble drug ritonavir via lyophilized milk-based solid dispersions. Pharm Dev Technol. 2017;22(1):90-102.

94. Rai VK, Dwivedi H, Yadav NP, Chanotiya CS, Saraf SA. Solubility enhancement of miconazole nitrate: binary and ternary mixture approach. Drug Dev Ind Pharm. 2014;40(8):1021-9.

95. Shaikh SM, Avachat AM. Enhancement of solubility and permeability of Candesartan cilexetil by using different pharmaceutical interventions. Curr Drug Deliv. 2011;8(4):346-53.

96. Li X, Yuan H, Zhang C, Chen W, Cheng W, Chen X, Ye X. Preparation and in-vitro/in-vivo evaluation of curcumin nanosuspension with solubility enhancement. J Pharm Pharmacol. 2016;68(8):980-8.

97. Nanotechnology Drug Delivery Market (By Technology - Nanocrystals, Nanoparticles, Liposomes, Micelles, Nanotubes, and Others; By Application - Neurology, Oncology, Cardiovascular/Physiology, Anti-inflammatory/Immunology, Anti-infective, and Others) - Global Industry Analysis, Size, Share, Growth, Trends, and Forecast 2015 2023. Available at https://www.transparencymarketresearch.com/ nanotechnology-drug-delivery.html accessed on 26/11/2018.

98. Poste G, Papahadjopoulos D, and Vail WJ. Lipid vesicles as carriers for introducing biologically active materials into cells. Methods in Cell Biol. 1976;14:33-71.

99. Merisko-Liversidge E, Liversidge GG, and Cooper ER. Nanosizing: a formulation approach for poorly water-soluble compounds. Eur $J$ Pharm Sci. 2004;18:113-20.
100. Rizvi SA, Saleh AM. Applications of nanoparticle systems in drug delivery technology. Saudi Pharma J. 2018;26(1):64-70.

101. Torchilin VP. Recent advances with liposomes as pharmaceutical carriers. Nature Rev Drug Disc. 2005;4(2):145.

102. Ansari MJ, Ahmed MM, Anwer MK, Jamil S, Alailaiwe A, Alshetaili AS, et al. Formulation and characterization of fluconazole loaded olive oil nano-emulsions. Indo Am J Pharm Sci. 2017, 4 (04), 852-60.

103. Ansari MJ. Factors Affecting Preparation and Properties of Nanoparticles by Nanoprecipitation Method. Indo Am. J. P. Sci. 2017; 4(12):4854-8.

104. Omolo CA, Kalhapure RS, Agrawal N, Rambharose S, Mocktar C, Govender T. Formulation and Molecular Dynamics Simulations of a Fusidic Acid Nanosuspension for Simultaneously Enhancing Solubility and Antibacterial Activity. Mol Pharm. 2018;15(8): 3512-26.

105. Aditya NP, Yang H, Kim S, Ko S. Fabrication of amorphous curcumin nanosuspensions using $\beta$-lactoglobulin to enhance solubility, stability, and bioavailability. Colloids Surf B Biointerfaces. 2015;127:114-21.

106. Kassem MAA, ElMeshad AN, Fares AR. Enhanced Solubility and Dissolution Rate of Lacidipine Nanosuspension: Formulation Via Antisolvent Sonoprecipitation Technique and Optimization Using Box-Behnken Design. AAPS PharmSciTech. 2017;18(4):983-96.

107. Telange DR, Patil AT, Pethe AM, Fegade H, Anand S, Dave VS Formulation and characterization of an apigenin-phospholipid phytosome (APLC) for improved solubility, in vivo bioavailability, and antioxidant potential. Eur J Pharm Sci. 2017;108:36-49.

108. Lee JS, Hong DY, Kim ES, Lee HG. Improving the water solubility and antimicrobial activity of silymarin by nanoencapsulation. Colloids Surf B Biointerfaces. 2017;154:171-7.

109. Arunkumar R, Prashanth KVH, Manabe Y, Hirata T, Sugawara T, Dharmesh SM, Baskaran V. Biodegradable Poly (Lactic-co-Glycolic Acid)-Polyethylene Glycol Nanocapsules: An efficient carrier for improved solubility, bioavailability, and anticancer property of lutein. J Pharm Sci. 2015;104(6):2085-93.

110. Groo AC, De Pascale M, Voisin-Chiret AS, Corvaisier S, Since M, Malzert-Fréon A. Comparison of 2 strategies to enhance pyridoclax solubility: Nanoemulsion delivery system versus salt synthesis. Eur J Pharm Sci. 2017;97:218-26.

111. Han M, He CX, Fang QL, Yang XC, Diao YY, Xu DH, He QJ, Hu YZ, Liang WQ, Yang B, Gao JQ. A novel camptothecin derivative incorporated in nano-carrier induced distinguished improvement in solubility, stability and anti-tumor activity both in vitro and in vivo. Pharm Res. 2009;26(4):926-35.

112. Bolko K, Zvonar A, Gašperlin M. Mixed lipid phase SMEDDS as an innovative approach to enhance resveratrol solubility. Drug Dev Ind Pharm. 2014;40(1):102-9.

113. Nandi I, Bari M, Joshi H. Study of isopropyl myristate microemulsion systems containing cyclodextrins to improve the solubility of 2 model hydrophobic drugs. AAPS PharmSciTech. 2003;4(1):E10. 